\title{
USAHA PENINGKATAN MOTIVASI UNTUK MENCIPTAKAN EFEKTIVITAS KERJA PADA KEJAKSAAN TINGGI KALIMANTAN TENGAH
}

\author{
Efforts to Increase Motivation to Create Work Effectiveness \\ in the Central Kalimantan High Prosecutor's Office
}

\section{Indah Megawati* \\ Dwiana Herawati}

Universitas Muhammadiyah

Palangkaraya, Palangka Raya, Central

Kalimantan, Indonesia

email:

indah.megawati@umpalangkaraya.ac.id

\begin{abstract}
Abstrak
Motivasi merupakan daya penggerak yang menciptakan kegairahan kerja sesorang agar mereka mau bekerja sama, bekerja efektif dan terintegrasi dengan segala daya upayanya untuk mencapai kepuasaan. Motivasi sebagaiknya dimiliki seseorang supaya bisa dengan mudah mencapai efektivitas kerja yang diharapkan. Tujuan penelitian ini adalah untuk mendapatkan gambaran yang jelas mengenai usaha peningkatan motivasi untuk menciptakan efektivitas kerja pada instansi Kejaksan Tinggi Kalimantan Tengah di Kota Palangka Raya. Populasi dari penelitian ini adalah seluruh pegawai instansi Kejaksaan Tinggi Kalimantan Tengah yang berjumlah 116 orang pegawai. Metode yang digunakam dalam penelitian ini adalah metode kuantitatif yang merupakan pendapat dari penulis atau berdasarkan teori-teori yang relevan dengan permasalahan dengan Teknik Data Kuantitatif yaitu data yang diperoleh melalui angka-angka selama proses tertentu.Hasil analisa data yang diperoleh berdasarkan tingkat kemangkiran pegawai dan tingkat absensi pegawai, dapat disimpulkan bahwa tingkat kemangkiran pegawai tahun 2015 : 40,42\%, tahun 2016 : 45,29\% dan tahun 2017 tingkat kemangkiran pegawai menjadi $52,65 \%$. Kemudian hasil data dari tingkat absensi pegawai tahun 2015 : 2,70\%, tahun 2016 : 3,60\% dan pada tahun 2017 tingkat absensi pegawai menjadi $5,45 \%$. Pada akhirnya, berhasil tidaknya usaha meningkatkan motivasi untuk mencipatkan efektivitas kerja pegawai pada Kejaksaan Tinggi Kalimantan Tengah di Palangka Raya, selain ditentukan oleh Pimpinan juga.
\end{abstract}

Kata Kunci:

Motivasi

Efektifitas

Kejaksaaan Tinggi

Keywords:

Motivation

Effectiveness

High Prosecutor's Office.

\section{Accepted}

June 2015

Published

October 2015

\begin{abstract}
Motivation is the driving force that creates enthusiasm for someone's work so that they will work together, work effectively and be integrated with all their efforts to achieve satisfaction. Motivation should be owned by someone so that they can easily achieve the expected work effectiveness. The purpose of this study is to get a clear picture of efforts to increase motivation to create work effectiveness in the Central Kalimantan High Prosecutor's Office in the City of Palangka Raya. The population of this study was all employees of the Central Kalimantan High Prosecutor's Office, amounting to II6 employees. The method used in this study is a quantitative method which is the opinion of the author or based on theories that are relevant to the problem with the Quantitative Data Technique, which is data obtained through numbers during a particular process. employee absenteeism, it can be concluded that the level of absenteeism of employees in 2015: $40.42 \%$, in 2016: $45.29 \%$ and in 2017 the level of absenteeism of employees becomes $52.65 \%$. Then the results of the data from the employee absentee level in 2015: $2.70 \%, 2016: 3.60 \%$ and in 2017 the employee absentee level becomes $5.45 \%$. In the end, the success of efforts to increase motivation to create work effectiveness of employees at the Central Kalimantan High Prosecutor's Office in Palangka Raya, besides being determined by the Chairperson as well.
\end{abstract}

\section{PENDAHULUAN}

Kejaksaan Tinggi Kalimantan Tengah bertindak sebagai penjamin kepastian hukum, kewibawaan pemerintah dan penyelamatan kekayaan negara berdasarkan peraturan perundang-undangan dan kebijaksanaan yang telah di tetapkan Kejaksaan Tinggi Kalimantan Tengah, dapat terlihat bahwa peranan pegawai sebagai sumber tenaga kerja dalam suatu unit instansi sangat 
dibutuhkan untuk menghasilkan kinerja yang berkualitas dan optimal.

Seorang pegawai dalam proses kerja mempunyai indentifikasi tersendiri yaitu mengenai perilaku, sikap, tabiat, kebiasaan yang tumbuh dan berkembang yang berbentuk oleh kondisi lingkungan dan pengalaman di tempat kerja. Disamping itu seorang pegawai juga manusia yang merupakan mahluk dinamis yang senantiasa berubah keinginan, kemampuan, kebutuhan, dan tuntutan hidupnya yang secara otomatis dapat mempengaruhi pegawai dalam melaksanakan pekerjaannya.

Dari semua peranan pegawai dalam meningkatkan fungsi manajemen dibutuhkan pengetahuan dari setiap pimpinan untuk berusaha mengetahui kebutuhan pegawai dalam hubungan antara pegawai dan pekerjaan serta memberikan motivasi kepada bawahannya untuk lebih berprestasi. Presetasi pegawai itu sendiri ditentukan oleh motivasi kerja dari pegawai itu sendiri. Motivasi tersebut yaitu yang terhadap dari dalam diri pegawai yang berupa dorongan, upaya dan keinginan yang ada didalam diri manusia yang mengaktifkan memberi daya, mengarahkan perilaku dalam mencapai tujuan dalam hal ini pelaksanaan tugas-tugas dalam limgkup pekerjaanya. Selain itu motivasi dalam diri pegawai juga dipemngaruhi kemampuan yang ditentukan oleh kualifikasi yang dimilikinya antara lain seperti pendidikan, penglaman, kareteristik pribadi. Motivasi tersebut juga ada yang datang dari luar dirinya yaitu motivasi yang dipengaruhi oleh imbalan yang diterima seseorang sesudah melakukan pekerjaanya, penghargaan atas prestasi kerjannya, jaminan kondisi kerja yang nyaman, dan afiliasi (perasaan diterima) dalam lingkungan sekitarnya.

Motivasi dapat juga dipadang sebagai bagian integral dari manajemen personalia dalam rangka proses pembinaan, pengembangan, dan pengarahan tenaga kerja dalam suatu instansi karena pegawai merupakan unsur penting, paling utama dan menentukan bagi kelancaran jalannya manajemen itu sendiri. Oleh karena itu masalah yang berhubungan dengan konsepsi motivasi perlu mendapat perhantian yang sungguhsungguh dari setiap orang yang berkepentingan dengan keberhasilan instansi Kejaksaan Tinggi Kalimantan Tengah dalam mewujudkan usaha kerjasama manusia untuk mencapai suatu tujuan yang telah ditetapkan.

Terkait hal tersebut, dalam melaksanakan tugastugasnya instansi Kejaksaan Tinggi Kalimantan Tengah perlu meningkatkan sumber daya manusia yang berdaya guna dan berhasil guna sesuai dengan perkembangan pembangunan sehingga dapat memberikan dorongan yang positif. Peningkatkan sumber daya manusia tersebut diharapkan nantinya dapat berpengaruh terhadap pelaksanaan kerja yang mengarah pada terselesainya tugas-tugas dengan tepat waktu sehinggs semua kegiatan berjalan efektif dalam pelaksaan kerja. Jadi jelaslah bahwa faktor motivasi merupakan salah satu hal yang sangat penting untuk menciptakan efektivitas kerja para pegawainya.

Menurut Terry (Hasibuan, 2013 :145) mengemukakan bahwa motivasi adalah keinginan yang terdapat pada diri seseorang individu yang merangsangnya untuk melakukan tindakan-tindakan.Selanjutnnya Sondang (2009:138) mengemukakan motivasi adalah daya pendorong yang mengakibatkan seorang anggota organisasi mau dan rela untuk mengerahkan kemampuan dalam bentuk keahlian atau keterampilan tenaga dan waktunya untuk menyelenggarakan berbagai kegiatan yang menjadi tanggung jawabnya dan menuaikan kewajibannya dalam rangka pencapian tujuan dan berbagai sasaran organisasi yang telah ditetapkan.

Efektivitas berasal dari kata efektif yang mengandung pengertian dicapainya keberhasilan dalam mencapai tujuan yang telah ditetapkan. Efektivitas selalu dengan hubungan antara hasil yang diharapkan dengan hasil yang sesungguhnya dicapai. Ada beberapa pendapat tentang efektivitas menurut para ahli sebagai berikut: 
Troton (Lie,2015:23) mengemukakan bahwa "Efektivitas dapat didefinisikan sebagai tingkat ketetapan dalam memilih atau menggunakan suatu metode untuk melakukan sesuatu".

Kemudian Emerson (Nasila,2013:6) mengemukakan bahwa "effectivitness is a measuring in term attaining prescribed goals or objective" (efektivitas adalah pengukuran dalam arti pencapaian sasaran atau tujuan yang ditentukan sebelumnya). Widjaja (Nasila,20I3:6) mengatakan bahwa" efektivitas adalah ukuran suatu organisasi dimana kemampuan organisasi untuk mencapai segala keperluannya, ini berarti organisasi mampu menyusun dan mengorganisasikan sumber daya untuk mencapai suatu tujuan”. Menurut Yusuf Suit Almasdi (2006:94), efektivitas kerja adalah ketepatan suatu tindakan atau kesempuranaan (jaminan) hasil suatu pekerjaan itu sendiri. Sondang P.Siagian (1982:5I).

Dalam kegiatan mendorong kegiatan para pegawai agar menggunakan kemampuan yang ada maka para pegawai diberi motivasi supaya timbul suatu keinginan terhadap suatu pekerjaan dengan melakukan kerjasama antar kelompok pegawai untuk suatu tujuan dalam pekerjaan. Jadi masalah motivasi harus mendapat perhatian yang dipandang sebagai usaha pembinaan, pengembangan, pengarahan tenaga kerja, karena sebagai bagian terpenting dan yang utama bagi kelangsungan instansi.

Suatu instansi tidak dapat melakukan aktivitasnya tanpa sumber daya manusia atau tenaga kerja didalamnya. Untuk menggerakan tenaga kerja yang ada pada instansi tersebut diperlukan pola manajemen serta langkah motivasi yang tepat. Oleh sebab itu berhasil tidaknya pihak instansi mencapai tujuan disamping pola manajemen yang kuat juga tergantung pada efektivitas kerja para pegawainya.

Barnard (Gibson et al, 1996:27) mengemukakan bahwa yang dimaksud dengan efektivitas merupakan pencapaian sasaran dari upaya bersama. Sehubung dengan hal itu, langkah pemberian motivasi menjadi mutlak adanya sebagai pendorong yang diberikan kepada seseorang agar bekerjasama untuk menciptakan efektivitas kerja. Tingkat efektivitas kerja akan tergantung kepada bagaimana pimpinan memberikan dorongan semangat dan apabila pegawai kurang motivasi atau rangsangan yang sifatnya menciptakan efektivitas kerja maka instansi tersebut tentu akan mengalami kemunduran.

Efektivitas kerja dapat dilihat dari kinerja yang telah dicapai yang dapat dihasilkan melalui motivasi pegawai pegawai dan kemampun yang dimilikinya. Menurut Rivai (wikipedia,2004:309) mengemukakan kinerja sebagai perilaku yang nyata ditampilkan setiap orang sebagai prestasi kerja yang dihasilkan sesuai dengan perannya dalam suatu lembaga.

\section{METODOLOGI}

Pendekatan yang digunakan dalam penelitian ini adalah penelitian kuantitatif. Populasi dari penelitian ini adalah seluruh pegawai instansi Kejaksaan Tinggi Kalimantan Tengah yang berjumlah 116 orang pegawai. Metode yang digunakam dalam penelitian ini adalah metode kuantitatif yang merupakan pendapat dari penulis atau berdasarkan teori-teori yang relevan dengan permasalahan dengan Teknik Data Kuantitatif yaitu data yang diperoleh melalui angka-angka selama proses tertentu.

\section{HASIL DAN PEMBAHASAN}

Berdasarkan hasil penelitian, penyebab keadaan belum terciptanya efektivitas kerja pegawai pada kejaksaan Tinggi Kalimantan Tengah di Palangka Raya tersebut dikarenakan :

I. Belum diterapkannya sanksi yang lebih tegas dari pimpinan puncak (Kepala Kejaksaan Tinggi) Terhadap bawahnnya yang tidak disiplin tersebut, sehingga karyawan tersebut tetap melakukan pelanggaran disiplin. Hal ini dikarenakan pengaruh 
sosial budaya bangs akita, pimpinan memberikan tenggang rasa agar mereka dapat menyesusaikan tetapi pegawai juga mempunyai kebiasaan yang sulit dirubah sehingga hanya dengan penegasan aturan dan kemauan untuk maju dari peroranganlah yang merubah tatanan tersebut.

2. Kurangnya wibawa atasan tingkat menengah dalam memotivasi atau menggerakan bawahan, sehingga bawahan merasa kurang dibimbing, diawasi dan diarahkan sebagaimana mestinya dalam bekerja, menyebabkan pekerjaan atau tugas yang dilakukan sering tidak efektif.

3. Masih kurangnya hubungan kerjasama yang baik antara atasan tingkat menengah dengan bawahanya, sehingga keluhan dan hambatan yang dihadapi bawahan dalam melaksanakan tugas kurang mendapat perhantian dari atasan tingkat menengah tersebut.

4. Faktor imbalan yang masih belum sesuai dengan kebutuhan perorangan dan kualifikasi pendidikan pegawai terhadap pegawai terhadap pekerjaan (tugas dan tanggung jawabnya) menyebabkan pegawai kurang termotivasi untuk lebih loyal dan berkompeten terhadap pekerjaanya

\section{KESIMPULAN}

Dalam pelaksanaan tugas pada Kejaksaan Tinggi Kalimantan Tengah sering terjadi ketidakefektifan dikarenakan dimulai dari atasan tingkat menengah dan hal ini diikuti oleh beberapa pegawai yang melalaikan tanggung jawab. Sehingga dalam melaksanakan tugasnya sering terjadi penyimpangan dari peraturan yang telah ditetapkan, hal ini dapat di lihat dari tingginya tingkat kemangkiran dan tingginya tingkat absensi.

Data yang diperoleh berdasarkan tingkat kemangkiran pegawai dan tingkat absensi pegawai dapat disimpulkan bahwa tingkat kemangkiran pegawai tahun 20I5-20I7 meningkat dari 40,42\% menjadi 52,65\% kemudian haisl data dari tingkat absensi pegawai tahun 20I5-20I7 masih meningkat, dari $2,70 \%$ menjadi 5,45\%. Berdasarkan data tersebut dapat dikatakan bahwa presentase pegawai yang tidak aktif sebesar 5,45\% dan pegawai yang aktif hanya mencapai $95,55 \%$ selama tiga periode.

Sehingga Perlu ditingkatkan hubungan kerjasama yang baik antara atasan tingkat menengah dengan para bawahan, sehingga apa yang menjadi kesulitan bawahan dalam pekerjaan dapat segera diketahui dan para pegawai merasa mendapat perhatian dari pimpinan yang memiliki sifat dan sikap yang juga mencoba untuk merubah untuk lebih menekankan keibawaan yang membawa pada sikap hormat dari pegawai. Untuk menciptakan efektivitas kerja pegawai hendaknya diberi sanksi yang lebih tegas dilakukan sesuai dengan peraturan yang berlaku. Tertutama terhadap pegawai yang tidak disiplin.

\section{REFERENSI}

Arikunto, Suharsimi, 2006. Prosedur Penelitian suatu Pendekatan Praktik. Jakarta : Bina Aksara.

Gibson. Ivancevich dan Donnelly, 1996. Organisasi Perilaku Struktur Proses. Jakarta : Erlangga.

Gomes, Fustino C. 2003. Manajemen Sumber Daya Manusia. Yogyakarta : Andi

Hadiningrat, S. 2004. Pengantar Studi Administrasi dan Manajemen. Jakarta : CV Haji Masagung.

Irham, Fahmi. 20I3. Perilaku Organisasi. Bandung : Alfabeta

Lie, Melati. 20I5. Efektivitas Pengukuran Kinerja Badan Kepegawaian Daerah Kota Palopo. Makasar: Universitas Hasanuddin.

Marbun, B.N.2003. Kamus Manajemen. Cetakan I. Jakarta : Pustaka Sinar Harapan.

Nasila, Jans Wilianto. 20I4. Efektivitas Program Daerah Pemberdayaan Masyarakat (PDPM) studi tentang Penanggulangan Kemiskinan Di kelurahan.

Sunarto. 2005. Mengelola Karyawan. Cetakan I. Yogyakarta : Amus.

Torang, Syamsir. 20I4. Organisasi \& Manajemen. Bandung : Alfabeta 